\title{
When Wet Gets Wetter: Decoupling of Moisture, Redox Biogeochemistry, and Greenhouse Gas Fluxes in a Humid Tropical Forest Soil
}

\author{
Steven J. Hall, ${ }^{1 *}$ William H. McDowell, ${ }^{2}$ and Whendee L. Silver ${ }^{1}$
}

\begin{abstract}
${ }^{1}$ Department of Environmental Science, Policy, and Management, University of California, Berkeley, 107 Mulford Hall, Berkeley, California 94720, USA; ${ }^{2}$ Department of Natural Resources and the Environment, University of New Hampshire, 56 College Rd, Durham, New Hampshire 03824, USA
\end{abstract}

\begin{abstract}
Upland humid tropical forest soils are often characterized by fluctuating redox dynamics that vary temporally and spatially across the landscape. An increase in the frequency and intensity of rainfall events with climate change is likely to affect soil redox reactions that control the production and emissions of greenhouse gases. We used a 24-day rainfall manipulation experiment to evaluate temporal and spatial trends of surface soil $(0-20 \mathrm{~cm})$ redox-active chemical species and greenhouse gas fluxes in the Luquillo Experimental Forest, Puerto Rico. Treatments consisted of a high rainfall simulation $\left(60 \mathrm{~mm} \mathrm{day}^{-1}\right)$, a fluctuating rainfall regime, and a control. Water addition generated high temporal and spatial variation in soil moisture $\left(0.3-0.6 \mathrm{~m}^{3} \mathrm{~m}^{-3}\right)$, but had no significant effect on soil oxygen $\left(\mathrm{O}_{2}\right)$ concentrations. Extractable nitrate $\left(\mathrm{NO}_{3}{ }^{-}\right)$ concentrations decreased with daily water additions and reduced iron $(\mathrm{Fe}(\mathrm{II}))$ concentrations increased towards the end of the experiment. Overall, redox indicators displayed a weak, non-deterministic, nonlinear relationship with soil moisture. High concentrations of $\mathrm{Fe}(\mathrm{II})$ and manganese (Mn) were present even where
\end{abstract}

moisture was relatively low, and net Mn reduction occurred in all plots including controls. Mean $\mathrm{CO}_{2}$ fluxes were best explained by soil $\mathrm{C}$ concentrations and a composite redox indicator, and not water addition. Several plots were $\mathrm{CH}_{4}$ sources irrespective of water addition, whereas other plots oscillated between weak $\mathrm{CH}_{4}$ sources and sinks. Fluxes of $\mathrm{N}_{2} \mathrm{O}$ were highest in control plots and were consistently low in water-addition plots. Together, these data suggest (1) a relative decoupling between soil moisture and redox processes at our spatial and temporal scales of measurement, (2) the co-occurrence of aerobic and anaerobic biogeochemical processes in well-drained surface soils, and (3) an absence of threshold effects from sustained precipitation on redox reactions over the scale of weeks. Our data suggest a need to re-evaluate representations of moisture in biogeochemical models.

Key words: biogeochemistry model; denitrification; global change; iron reduction; manganese reduction; methane; nitrous oxide; oxygen; precipitation; soil respiration.
Received 26 August 2012; accepted 26 November 2012; published online 22 December 2012

Author Contributions: SJH designed and performed the study and wrote the paper, WLS contributed to design and writing, WHM contributed to analysis and writing.

*Corresponding author; e-mail: stevenhall@berkeley.edu

\section{INTRODUCTION}

Humid tropical forests exert substantial influence on the atmospheric concentrations of the greenhouse gases carbon dioxide $\left(\mathrm{CO}_{2}\right)$, nitrous oxide $\left(\mathrm{N}_{2} \mathrm{O}\right)$, and methane $\left(\mathrm{CH}_{4}\right)$. These ecosystems 
generate the highest soil-atmosphere $\mathrm{CO}_{2}$ fluxes of any biome, provide the largest natural source of $\mathrm{N}_{2} \mathrm{O}$, and are increasingly thought to provide a substantial net source of $\mathrm{CH}_{4}$ (Matson and Vitousek 1990; Raich and Schlesinger 1992; Carmo and others 2006; Bloom and others 2010). Although the net $\mathrm{C}$ balance of humid tropical forest soils remains uncertain, they contain a significant portion (approximately $500 \mathrm{Pg}$ ) of the terrestrial organic carbon (C) pool (Jobbagy and Jackson 2000). Global climate change is likely to affect soil $\mathrm{C}$ storage and greenhouse gas fluxes from humid tropical forest soils, yet the relative impact of different environmental drivers remains poorly understood. The stimulation of organic matter decomposition rates under increasing temperatures has been widely acknowledged (Davidson and Janssens 2006), but the biogeochemical impacts of altered precipitation regimes have received less attention. Drought can potentially increase or decrease soil respiration in humid tropical forests (Wood and Silver 2012; Cleveland and others 2010), but potential consequences of short-term variability in precipitation (days to weeks) have not yet been closely examined. Theoretical and empirical evidence points to an increase in the frequency and magnitude of extreme precipitation events with global climate change (Karl and others 1995; Romps 2011). Variability in soil moisture has long been known to impact soil oxygen $\left(\mathrm{O}_{2}\right)$ concentrations, especially in the humid tropics where increased rainfall often correlates with declines in $\mathrm{O}_{2}$, presumably due to decreased gasphase diffusion (Vine and others 1942; Silver and others 1999). Rainfall-induced variability in $\mathrm{O}_{2}$ concentrations could generate important feedbacks on the redox-sensitive biogeochemical reactions controlling soil greenhouse gas production. Oxygen provides the most energetically favorable electron acceptor for microbial respiration, and directly inhibits production of $\mathrm{N}_{2} \mathrm{O}$ and $\mathrm{CH}_{4}$ due to lower energy yields from denitrification and methanogenesis (Megonigal and others 2003). Although the importance of anaerobic biogeochemical cycling of $\mathrm{C}$, nitrogen $(\mathrm{N})$, manganese $(\mathrm{Mn})$, iron $(\mathrm{Fe})$, and sulfur (S) have long been documented in wetland ecosystems (Ponnamperuma 1972), the significance of anaerobic processes such as Fe reduction and methanogenesis has only recently been recognized in upland humid tropical forest soils (Peretyazhko and Sposito 2005; Teh and others 2005; Chacon and others 2006). Understanding the environmental drivers of aerobic and anaerobic biogeochemical reactions in upland humid tropical forests could provide insight into dynamics of soil greenhouse gas fluxes from these ecosystems.
The presence of soil moisture concentrations above field capacity or flooded conditions are typically accepted as critical constraints for inducing soil $\mathrm{O}_{2}$ depletion. Water table depth and time since flooding have provided effective proxies for redox conditions and $\mathrm{CO}_{2}$ and $\mathrm{CH}_{4}$ fluxes across a range of wetland ecosystems (Ponnamperuma 1972; Jungkunst and Fiedler 2007). Studies in upland soils have also shown suppression of soil respiration by high soil moisture, presumably due to $\mathrm{O}_{2}$ depletion (Linn and Doran 1984). Because soil moisture is a relatively tractable variable, relationships between moisture and redox processes have been incorporated into mechanistic models used to describe soil redox dynamics, organic matter decomposition, and trace gas fluxes (Li and others 1992; Parton and others 1993). Building on research in temperate ecosystems, work in the humid tropics has suggested that soil moisture dominantly influences the redox reactions that control greenhouse gas fluxes. Several studies suggested that suppression of microbial organic matter decomposition under anaerobic conditions could explain observations of declining $\mathrm{CO}_{2}$ fluxes under high soil moisture, in addition to the impact of decreased diffusivity (Schuur and Matson 2001; Chambers and others 2004; Cleveland and others 2010). Fluxes of $\mathrm{N}_{2} \mathrm{O}$ from humid tropical forest soils often exhibit positive relationships with soil moisture indicative of stimulated denitrification rates (Keller and Reiners 1994; Erickson and others 2001; Koehler and others 2009; Rowlings and others 2012). And, although humid tropical soils have previously been thought to provide a net $\mathrm{CH}_{4}$ sink in the absence of disturbance (Keller and Reiners 1994; Steudler and others 1996; Rowlings and others 2012), recent data suggest the presence of a cryptic $\mathrm{CH}_{4}$ source in these ecosystems likely related to moisture variability (Teh and others 2005; Carmo and others 2006). Other studies demonstrated that rainfall can shift soils from $\mathrm{CH}_{4}$ sinks to sources (Vasconcelos and others 2004; Yu and others 2008; Itoh and others 2009), and it is unknown whether this relationship is widespread. In particular, we ask whether variation in the magnitude and duration of rainfall and soil moisture is sufficient to explain dynamics of redox reactions and greenhouse gas fluxes in upland humid tropical forests.

The relationships between moisture and greenhouse gas fluxes discussed above are underpinned by theoretical differences in the thermodynamic energy yield of soil microbe-catalyzed redox reactions. Theory suggests that electron acceptors should be reduced in a predictable sequence, 
provided that microbes compete for electron donors (for example, labile C) in a spatially homogeneous environment. Oxygen should be respired first, followed by nitrate $\left(\mathrm{NO}_{3}\right)$, manganese oxides $(\mathrm{Mn}(\mathrm{IV}))$, iron oxides $(\mathrm{Fe}(\mathrm{III}))$, sulfate $\left(\mathrm{SO}_{4}\right)$, and finally $\mathrm{CO}_{2}$ (Megonigal and others 2003). The terminal electron-accepting process (TEAP) model posits that dominant redox processes can be identified by evaluating spatial or temporal trends in the concentrations of electron acceptors and reduced products (Chapelle and others 1995). This framework provided insight into understanding the dynamics of redox reactions and greenhouse gas production across diverse wetland, sediment, and aquifer ecosystems (Achtnich and others 1995; Chapelle and others 1995; Hedin and others 1998; $\mathrm{Yu}$ and others 2007). As $\mathrm{O}_{2}$ and other terminal electron acceptors are successively depleted, the production of $\mathrm{CO}_{2}, \mathrm{~N}_{2} \mathrm{O}$, and $\mathrm{CH}_{4}$ often varies characteristically over time. Carbon dioxide production typically decreases monotonically, $\mathrm{N}_{2} \mathrm{O}$ production peaks and then declines, and $\mathrm{CH}_{4}$ production exhibits a threshold increase after other terminal electron acceptors have been depleted (Achtnich and others 1995; Yu and others 2007). The utility of this model to predict temporal and spatial patterns of redox reactions and greenhouse gas fluxes remains largely untested in upland humid tropical soils.

Well-drained upland humid tropical forest soils can experience sub-atmospheric $\mathrm{O}_{2}$ concentrations due to a combination of high moisture and respiration rates. Soil $\mathrm{O}_{2}$ concentrations in Puerto Rican forests correlated with differences in total rainfall at a landscape scale and with temporal variability in rainfall within sites over days to weeks (Silver and others 1999; Liptzin and others 2011). However, the relative influence of soil moisture on redox reactions and greenhouse gas fluxes has not been tested in these ecosystems, especially as compared with other soil characteristics such as $\mathrm{C}$ concentration. Given the rapid infiltration rates characteristic of these soils (McDowell and others 1992) and the potential for infiltrating water to supply dissolved $\mathrm{O}_{2}$ to microbes, we expect a more nuanced relationship between rainfall, soil moisture, and redox processes in this ecosystem. Here, we tested the influence of soil moisture on redox reactions and greenhouse gas fluxes using a 24-day water-addition experiment to amplify differences in soil moisture among plots. This timescale is relevant to the underlying periodicity of rainfall and $\mathrm{O}_{2}$ fluctuations in this ecosystem, given that sustained periods of high precipitation and bulk soil $\mathrm{O}_{2}$ depletion occur on scales of days to weeks
(Heartsill-Scalley and others 2007; Liptzin and others 2011). Our 24-day water-addition treatment represents an extreme but plausible end-member of potential rainfall scenarios. Dominant redox processes can shift over scales of days to weeks in wetland ecosystems (Achtnich and others 1995; Ratering and Conrad 1998), and we predicted similar rapid responses in our tropical forest ecosystem given the facultative anaerobic capacity of the endemic microbial community (Pett-Ridge and Firestone 2005). We compared patterns in the concentrations of electron acceptors $\left(\mathrm{O}_{2}, \mathrm{NO}_{3}\right.$, and $\mathrm{SO}_{4}$ ) and reduced products ( $\mathrm{Mn}(\mathrm{II}), \mathrm{Fe}(\mathrm{II})$, and soil $\mathrm{CH}_{4}$ ) as relative indicators of redox reactions. We predicted that sustained high soil moisture would deplete electron acceptors, correlating with a decline in $\mathrm{CO}_{2}$ fluxes, a brief period of elevated $\mathrm{N}_{2} \mathrm{O}$ fluxes, and an eventual increase in $\mathrm{CH}_{4}$ fluxes. We also predicted that shorter periods (days) of high soil moisture would suppress $\mathrm{CO}_{2}$ fluxes, but would be insufficient to deplete electron acceptors and stimulate net positive $\mathrm{CH}_{4}$ fluxes.

\section{MethodS}

\section{Study Area}

We conducted our experiment in the Bisley Watershed of the Luquillo Experimental Forest, Puerto Rico $\left(18.3^{\circ} \mathrm{N},-65.8^{\circ} \mathrm{W}\right)$, an NSF-funded Long-Term Ecological Research and Critical Zone Observatory site. This subtropical wet forest ecosystem experiences a long-term mean precipitation of $3500 \mathrm{~mm} \mathrm{y}^{-1}$ and mean annual temperature of $23^{\circ} \mathrm{C}$ (Scatena 1989). Seasonal variation in rainfall is relatively low, with a minimum in March $\left(5.6 \pm 0.7 \mathrm{~mm} \mathrm{day}^{-1}\right)$ and maximum in May $\left(11.7 \pm 1.3 \mathrm{~mm} \mathrm{day}^{-1}\right)$ from 1988 to 2003 (Heartsill-Scalley and others 2007). Extreme precipitation events exceeding $100 \mathrm{~mm} \mathrm{day}^{-1}$ can occur during any month, and most years experience several weeks of precipitation above $30 \mathrm{~mm} \mathrm{day}^{-1}$. Inter-annual precipitation is highly variable, ranging from 2600 to $5800 \mathrm{~mm} \mathrm{y}^{-1}$ between 1989 and 2011 (F. Scatena, unpublished data). Bisley watershed soils are ultisols supporting mature closed-canopy forest dominated by tabonuco (Dacryodes excelsa) and sierra palms (Prestoea montana) (Huffaker 2002). Overland flow of water is rare in these upland soils given that infiltration rates $\left(0.07-1.5 \mathrm{~cm} \mathrm{~min}^{-1}\right)$ typically exceed rainfall (0.1 cm min ${ }^{-1}$; McDowell and others 1992). Soil depth varies with topographic position in the Bisley watersheds and measures approximately $40 \mathrm{~cm}$ to saprolite in our experimental site. Surface soils 
$(0-20 \mathrm{~cm})$ have mean clay, silt, and sand contents of 39, 51, and $11 \%$, respectively (T. Natake, unpublished data), with a mean bulk density of $0.7 \mathrm{~g} \mathrm{~cm}^{-3}$.

\section{Experimental Design}

We established 18 plots measuring $1.25 \times 1.25 \mathrm{~m}$ within a $20 \times 30-\mathrm{m}$ area in an upland valley (Scatena 1989). Plots were assigned to one of three treatments: daily water additions for 24 days ("continuous" treatment); a regime consisting of 8 days of water addition followed by 8 days of throughfall exclusion and a final 8 days of water addition ("fluctuating" treatment); an un-manipulated control. Plot size was chosen to allow high replication within a relatively homogeneous landscape position while minimizing soil variability within a plot, and we positioned plots to avoid effects of downslope water movement. Throughfall was excluded for 8 days in the fluctuating treatment using transparent plastic shelters suspended $1 \mathrm{~m}$ above the plot surface. Each simulated rainfall event amounted to the addition of approximately $60 \mathrm{~mm} \mathrm{day}^{-1}$ of water collected from a nearby first-order stream. This water-addition regime represents a high but realistic amount of precipitation that normally occurs for at least 1 week per year (Heartsill-Scalley and others 2007). Water was added via perforated transparent plastic trays suspended approximately $10 \mathrm{~cm}$ above the plot surface, from which water slowly percolated onto the soil. Trays were removed from plots between watering events. Our 24-day continuous watering treatment provided an end member of realistic precipitation patterns to test the response of redox reactions to sustained precipitation inputs. We conducted the experiment during October 2010.

\section{Data Collection}

Soil moisture and $\mathrm{O}_{2}$ concentrations were measured quasi-continuously in each plot $(n=18)$ at 30-minute intervals for 2 months prior to and during the experiment using time-domain reflectometry (Campbell Scientific, Logan, Utah) and galvanic cell sensors (Apogee Instruments, Logan, Utah) connected to a datalogger. Oxygen sensors were calibrated to local pressure and mean soil temperature at $100 \%$ relative humidity, and were installed inside equilibration chambers consisting of $10-\mathrm{cm}$-long polyvinyl-chloride tubes $(5 \mathrm{~cm}$ diameter) with an open bottom and sealed top with a sampling port (three-way stopcock). These chambers were installed at a depth of $10 \mathrm{~cm}$ after removing an equivalent volume of soil, and $30 \mathrm{ml}$ of headspace gas was sampled with a syringe at 4-day intervals throughout the experiment to measure concentrations of $\mathrm{CO}_{2}$, $\mathrm{N}_{2} \mathrm{O}$, and $\mathrm{CH}_{4}$ (see below). Temperature sensors were installed at a depth of $10 \mathrm{~cm}$ in a subset of plots $(n=2$ per treatment). Moisture sensors provided an integrated measurement of the $0-20 \mathrm{~cm}$ depth, the predominant location of roots and organic matter in this ecosystem (Odum and others 1970).

Soil-atmosphere fluxes of $\mathrm{CO}_{2}, \mathrm{CH}_{4}$, and $\mathrm{N}_{2} \mathrm{O}$ were measured in each plot immediately prior to the experiment and at 2-day intervals thereafter using a vented static flux chamber technique (total $n=234$ ), with chamber collars removed between measurements. Chamber collars $(26 \mathrm{~cm}$ diameter) were installed to $3 \mathrm{~cm}$ depth and removed 2 months prior to the experiment. Collars were subsequently installed in the same positions during measurements to minimize artifacts due to root mortality and decay (Keller and others 2000). Mean height of the collar and chamber assembly was $18 \mathrm{~cm}$. Gas concentrations were measured using a gas chromatograph (Shimadzu, Columbia, Maryland) equipped with a flame ionization detector, thermal conductivity detector, and electron capture detector for $\mathrm{CH}_{4}, \mathrm{CO}_{2}$, and $\mathrm{N}_{2} \mathrm{O}$, respectively. Fluxes were calculated by fitting gas concentration data from five samples collected over 40 min to a model derived from Fick's first law (Matthias and others 1978). This nonlinear model accounts for inhibitory effects from increasing gas concentrations on fluxes throughout the measurement period.

Soils were sampled for chemical extraction prior to the experiment and at 8-day intervals thereafter. We composited three replicate $1.6-\mathrm{cm}$-diameter soil cores $(20 \mathrm{~cm}$ depth) for each plot. Separate replicate subsamples of each soil were extracted for $60 \mathrm{~min}$ in 1:10 slurries of $0.5 \mathrm{M}$ hydrochloric acid $(\mathrm{HCl})$ and filtered to $0.22 \mu \mathrm{m}$ for Fe(II) and Mn analysis, and 1:5 slurries of potassium chloride and ammonium acetate were extracted and filtered to 10 and $0.22 \mu \mathrm{m}$ for analysis of nitrate $\left(\mathrm{NO}_{3}{ }^{-}\right)$and sulfate $\left(\mathrm{SO}_{4}{ }^{2-}\right)$, respectively. Potassium chloride extractions were subsequently combined with a phosphate solution and filtered to $0.45 \mu \mathrm{m}$ to eliminate analytical interference from Fe (Yang and others 2012). We assumed that HCl-extractable Mn predominantly represents divalent reduced $\mathrm{Mn}(\mathrm{Mn}(\mathrm{II}))$. We measured Fe(II) using a ferrozine assay accounting for interference from Fe(III) (Viollier and others 2000), Mn using inductively coupled plasma atomic emission spectroscopy, $\mathrm{NO}_{3}{ }^{-}$using cadmium reduction and colorimetry, and $\mathrm{SO}_{4}{ }^{2-}$ using ion chromatography. Soil solutions were sampled from tension lysimeters (Prenart Super Quartz, Denmark) installed within $20 \mathrm{~cm}$ of the center of each plot at a 
depth of $10 \mathrm{~cm}$. We sampled lysimeters at 4-day intervals when yield was sufficient, filtered (precombusted Whatman GF-F), and frozen prior to analysis at University of New Hampshire by ion chromatography and combusted for measurement of dissolved organic C (DOC) on a Shimadzu TOC-V. We acidified a subset of soil solution samples with $\mathrm{HCl}$ to $\mathrm{pH}$ below 2 in the field for $\mathrm{Fe}(\mathrm{II})$ analysis (as above) when sufficient volume was available. Soil C was measured in pre-treatment samples (air-dried and ground) from all plots by combustion on a CE Elantech elemental analyzer (Lakewood, New Jersey).

We modeled soil diffusivity for $\mathrm{CO}_{2}$ using the Millington and Shearer (1971) model for aggregated porous media, incorporating diffusion through inter-aggregate and intra-aggregate pores. We estimated intra-aggregate porosity using volumetric soil moisture content at field capacity determined 2 days after a saturating rainfall event (Davidson and Trumbore 1995). Replicate measurements of field capacity among plots agreed closely (slope $=0.95, R^{2}=0.96$ ).

\section{Data Analysis}

Response variables were analyzed using mixedeffects models that incorporated random effects for plots and temporal autocorrelation implemented using the nlme library in $\mathrm{R}$ (Pinheiro and others 2011). The optimal random effect structure was selected using likelihood ratio tests after saturating the model with fixed effects. Fluxes of $\mathrm{CO}_{2}$ and $\mathrm{N}_{2} \mathrm{O}$ were log-transformed and fourth-root transformed, respectively, to satisfy model assumptions. Nonlinear trends were analyzed using additive mixed models implemented in the mgcv package in R (Wood 2006). Briefly, additive models fit a nonparametric smooth function to data with an optimum complexity chosen by an information criteria approach. For these models, we describe the significance, approximate variance explained, and approximate degrees of freedom (d.f.) of the smooth function, which provides a measure of the curvature of the function. For example, a smooth function with three d.f. would have three inflection points. In addition, we summarized the co-variation among redox species sampled within a given plot using principal components analysis.

\section{Results}

\section{Moisture Dynamics}

The continuous water-addition treatment maintained soils above field capacity for the duration of

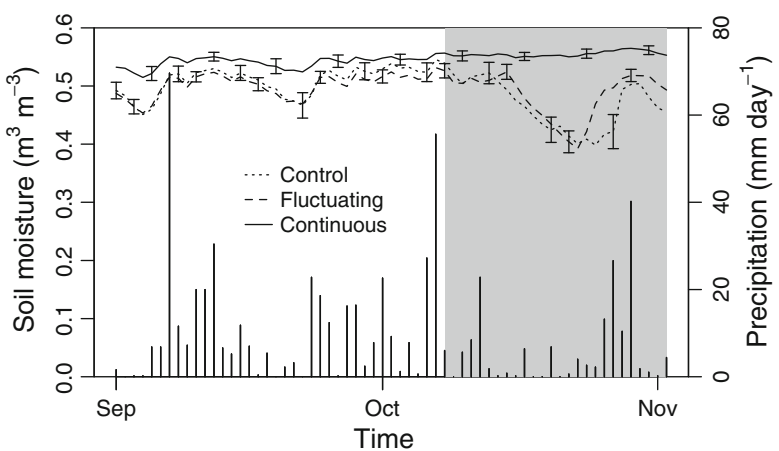

Figure 1. Precipitation and soil moisture $\left(\mathrm{m}^{3} \mathrm{~m}^{-3}\right) \pm \mathrm{SE}$ by treatment. The period of treatment application is shown in the shaded rectangle.

the experiment, whereas the fluctuating and control treatments exhibited a pronounced decline in soil moisture $\left(0.2 \mathrm{~m}^{3} \mathrm{~m}^{-3}\right)$ during the middle 8 days of the experiment coinciding with a period of low rainfall, and a subsequent increase in moisture to initial levels (Figure 1). Water addition to the fluctuating treatment did not increase soil moisture relative to the controls, likely due to several substantial $(>20 \mathrm{~mm})$ rain events at the beginning and end of the experiment. The continuously watered plots had slightly but significantly greater soil moisture than the other treatments before the experiment. Mean daily soil temperature averaged $24.3^{\circ} \mathrm{C}$ and varied by less than $1^{\circ} \mathrm{C}$ over the experiment, and did not differ among treatments.

\section{Variation Among Redox Species}

Oxygen concentrations were not significantly affected by either water supplementation treatment and showed relatively little temporal variation as compared with the other redox species (Figure 2). To account for spatial variation among plots, we report all redox species and gas flux data normalized to pre-treatment levels. Our additive model of $\mathrm{O}_{2}$ concentrations showed a significant nonlinear increase over time that was similar across all treatments $(P<0.05$, smooth function with approximately 1.4 d.f.). Soil $\mathrm{NO}_{3}{ }^{-}$concentrations were initially similar among treatments and approximately doubled in the control and fluctuating treatments over the experiment, whereas $\mathrm{NO}_{3}{ }^{-}$in continuously watered treatments measured only $44 \%$ of the other treatments in the final samples (treatment contrast $P<0.05$, Figure 2B). Lysimeter $\mathrm{NO}_{3}{ }^{-}$concentrations were initially low but increased significantly during the middle of the experiment in control and fluctuating treatments, coinciding with a decline in soil moisture (Figure 2F). Lysimeter $\mathrm{NO}_{3}{ }^{-}$remained consistently 

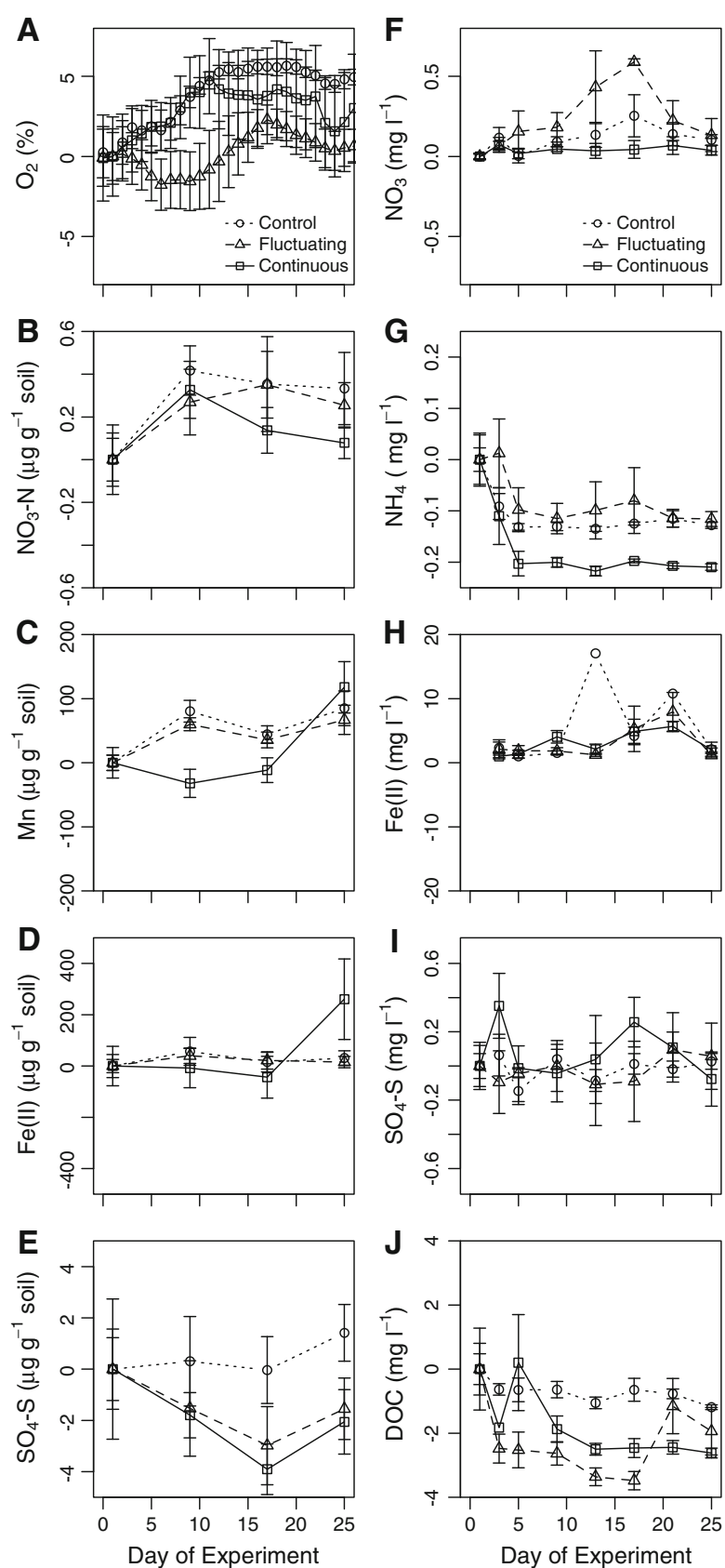

Figure 2. Soil atmosphere concentrations of $\mathrm{O}_{2}$ at $10 \mathrm{~cm}$ (A), KCl-extractable soil $\mathrm{NO}_{3}(\mathbf{B})$, $\mathrm{HCl}$-extractable $\mathrm{Mn}(\mathrm{II})$ and $\mathrm{Fe}(\mathrm{II})(\mathbf{C}, \mathbf{D})$, and ammonium acetate-extractable $\mathrm{SO}_{4}(\mathbf{E})$. The right-hand column shows lysimeter concentrations of $\mathrm{NO}_{3}(\mathbf{F}), \mathrm{NH}_{4},(\mathbf{G}) \mathrm{Fe}(\mathrm{II})(\mathbf{H}), \mathrm{SO}_{4}(\mathbf{I})$, and dissolved organic carbon $(\mathbf{J})$. Data $( \pm \mathrm{SE})$ are normalized to pre-treatment values.

low in the continuously watered treatment, and lysimeter $\mathrm{NH}_{4}{ }^{+}$concentrations declined significantly in all treatments over the experiment (Figure $2 \mathrm{G}$ ).

Net Mn reduction occurred in all treatments, with final extractable $\mathrm{Mn}$ (II) concentrations reaching 182,159 , and $150 \%$ of initial concentrations in the control, fluctuating, and continuous treatments, respectively (time effect $P<0.001$, Figure 2C). Soil Fe(II) concentrations were largely static in control and fluctuating plots, but $\mathrm{Fe}(\mathrm{II})$ concentrations increased by $98 \%$ in continuously watered plots from Day 18 to 25 , reflecting considerable net $\mathrm{Fe}$ reduction (treatment by time interaction, $P<0.05$, Figure 2D). In contrast, lysimeter $\mathrm{Fe}(\mathrm{II})$ concentrations showed considerable temporal variability across all treatments with large increases on Days 17 and 21 (Figure 2H). Both soil and lysimeter $\mathrm{SO}_{4}{ }^{2-}$ concentrations showed the least temporal variation of all the redox species (Figure 2E, I). Lysimeter DOC concentrations generally showed similar trends among treatments, but showed a secondary peak in the fluctuating treatment on Days 21 and 25 (Figure $2 \mathrm{~J}$ ). Control and continuously watered plots had similar DOC concentrations over most of the experiment.

Oxygen concentrations displayed a significant nonlinear pairwise negative relationship with soil moisture $\left(R^{2}=0.33, P<0.0001\right.$, smooth function with 3.7 d.f., Figure $3 \mathrm{~A}$ ). Oxygen concentrations below the detection limit were occasionally recorded above $55 \%$ soil moisture (Figure $3 \mathrm{~A}$ ). Continuous water addition was not sufficient to deplete soil $\mathrm{O}_{2}$, however, and $\mathrm{O}_{2}$ frequently approached atmospheric concentrations even at high soil moisture $\left(>0.55 \mathrm{~m}^{3} \mathrm{~m}^{-3}\right)$. Redox-active chemical species measured in the soil atmosphere and soil extractions $\left(\mathrm{O}_{2}, \mathrm{NO}_{3}{ }^{-}, \mathrm{Mn}(\mathrm{II}), \mathrm{Fe}(\mathrm{II})\right.$, and $\mathrm{CH}_{4}$ ) correlated according to thermodynamic predictions when analyzed together using principal component analysis; the first principal component explained $48 \%$ of their combined co-variation (Table 1). That is, lower concentrations of $\mathrm{O}_{2}$ and $\mathrm{NO}_{3}{ }^{-}$were associated with increased $\mathrm{Mn}(\mathrm{II})$, $\mathrm{Fe}(\mathrm{II})$, and $\mathrm{CH}_{4}$, but not in a step-wise manner. Sulfate was not significantly correlated with the other redox species. The first principal component of redox species displayed a negative nonlinear relationship with soil moisture similar to the relationship between $\mathrm{O}_{2}$ and soil moisture $\left(R^{2}=0.38, P<0.001\right.$, smooth function with 2 d.f., Figure $3 \mathrm{~B})$.

\section{Greenhouse Gas Fluxes}

Fluxes of $\mathrm{CO}_{2}$ varied significantly over time but showed similar temporal trends across all treatments (one smooth function with 7.8 d.f. $P<0.0001)$. Moisture and $\mathrm{O}_{2}$ concentrations were significantly correlated with $\mathrm{CO}_{2}$ fluxes (moisture: 

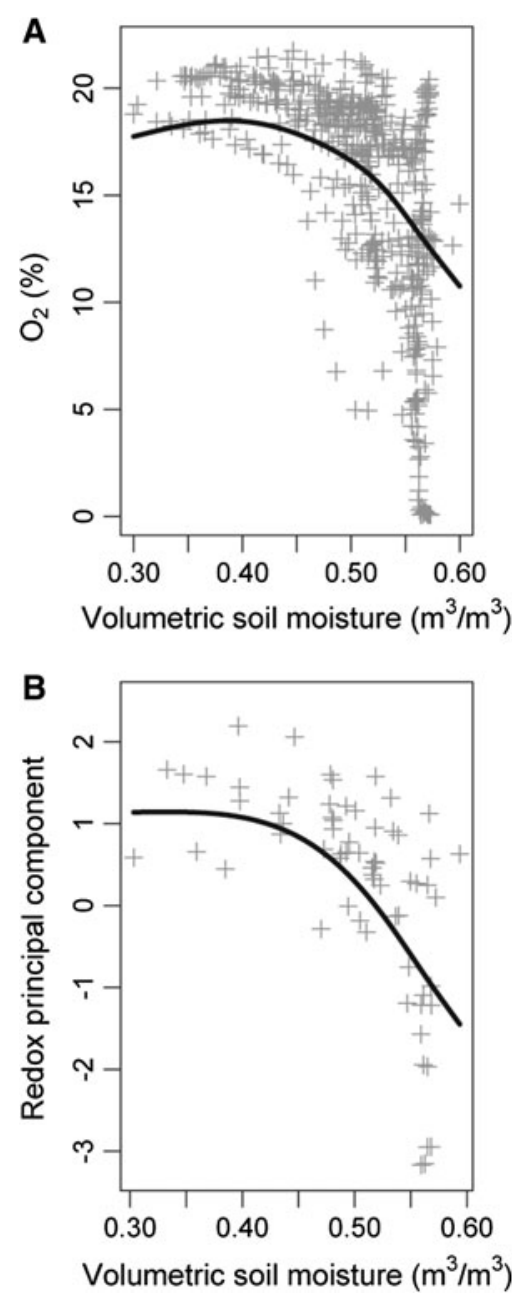

Figure 3. Relationships between daily mean volumetric soil moisture and $\mathrm{O}_{2}$ concentrations measured at $10 \mathrm{~cm}$ depth $(\mathbf{A})$, and the first principal component of redox species $\left(\mathrm{O}_{2}, \mathrm{NO}_{3}, \mathrm{Mn}(\mathrm{II}), \mathrm{Fe}(\mathrm{II}), \mathrm{CH}_{4}\right.$ concentrations) measured at 8-day intervals $(\mathbf{B})$.

Table 1. Principal Components Analysis of Co-variation Among Redox-active Chemical Species Sampled at Eight-Day Intervals over the Experiment

\begin{tabular}{lcl}
\hline Species & PCA loading & Redox state \\
\hline $\mathrm{O}_{2}$ & -0.44 & Oxidized \\
$\mathrm{NO}_{3}$ & -0.28 & Oxidized \\
$\mathrm{Mn}(\mathrm{II})$ & 0.51 & Reduced \\
$\mathrm{Fe}(\mathrm{II})$ & 0.5 & Reduced \\
$\mathrm{CH}_{4}$ & 0.47 & Reduced
\end{tabular}

PCA loading represents relationships between chemical species and the first principal component, which explained $48 \%$ of the variance among redox species.

negative correlation, $P<0.001$ and $\mathrm{O}_{2}$ : positive correlation, $P<.04)$, but explained comparatively little variation ( $8 \%$ of the sum of squares). Instead, constitutive spatial variation in $\mathrm{CO}_{2}$ fluxes (plot random effects) accounted for $81 \%$ of the model sum of squares. Modeled diffusivity correlated only weakly with $\mathrm{CO}_{2}$ fluxes $\left(R^{2}=0.07, P<0.01\right)$. Soil $\mathrm{CO}_{2}$ concentrations at $10 \mathrm{~cm}$ were more variable than $\mathrm{CO}_{2}$ surface fluxes, especially in the control plots where $\mathrm{CO}_{2}$ declined to $33 \%$ of initial concentrations between Days 1 and 17 (Figure 4B). Changes in soil $\mathrm{CO}_{2}$ concentrations did not significantly correlate with surface fluxes. When we averaged $\mathrm{CO}_{2}$ fluxes over time by plot they correlated significantly with soil $\mathrm{C}$ concentrations $(P<0.01$, Figure 5A) and with the first principal component of redox species $(P<0.05$, Figure $5 \mathrm{~B})$, which together explained $62 \%$ of the variation in mean $\mathrm{CO}_{2}$ fluxes among plots.

Nitrous oxide fluxes were lowest in continuously watered plots and were highest and most variable in the control plots (Figure 4C). Fluxes of $\mathrm{N}_{2} \mathrm{O}$ were significantly related to moisture, $\mathrm{O}_{2}$, and their interaction $(P=0.01$ for all three terms), with the highest $\mathrm{N}_{2} \mathrm{O}$ fluxes occurring at intermediate $\mathrm{O}_{2}$ and moisture $\left(18 \%\right.$ and $0.5 \mathrm{~m}^{3} \mathrm{~m}^{-3}$, respectively, Figure $5 \mathrm{C}, \mathrm{D})$. Dynamics of soil $\mathrm{N}_{2} \mathrm{O}$ concentrations did not follow those of surface fluxes. Soil $\mathrm{N}_{2} \mathrm{O}$ concentrations were typically highest in the continuously watered plots, whereas surface fluxes were lowest in this treatment (Figure 4D).

Fluxes of $\mathrm{CH}_{4}$ were not significantly related to $\mathrm{O}_{2}$ or moisture. Although net positive $\mathrm{CH}_{4}$ fluxes typically occurred at high soil moisture (Figure 5E), positive fluxes were also observed in plots with nearatmospheric soil $\mathrm{O}_{2}$ concentrations (Figure $5 \mathrm{~F}$ ). Mean $\mathrm{CH}_{4}$ fluxes averaged over the experiment showed a significant correlation with the redox principal component $\left(P=0.02, R^{2}=0.30\right)$. Soil $\mathrm{CH}_{4}$ concentrations $(10 \mathrm{~cm}$ depth) typically exceeded atmospheric levels in all plots.

\section{Discussion}

\section{Redox Species}

Research over the last decade has highlighted the importance of anaerobic metabolic processes such as $\mathrm{Fe}$ reduction and methanogenesis in upland forest soils (Silver and others 1999; Peretyazhko and Sposito 2005; Teh and others 2005; Chacon and others 2006; Thompson and others 2006; Fimmen and others 2008; Liptzin and Silver 2009; Dubinsky and others 2010). The spatial and temporal dynamics of redox reactions in these soils are generally assumed to vary with soil moisture. In this study, volumetric soil moisture ranged between 0.3 and $0.6 \mathrm{~m}^{3} \mathrm{~m}^{-3}$ among plots, yet 

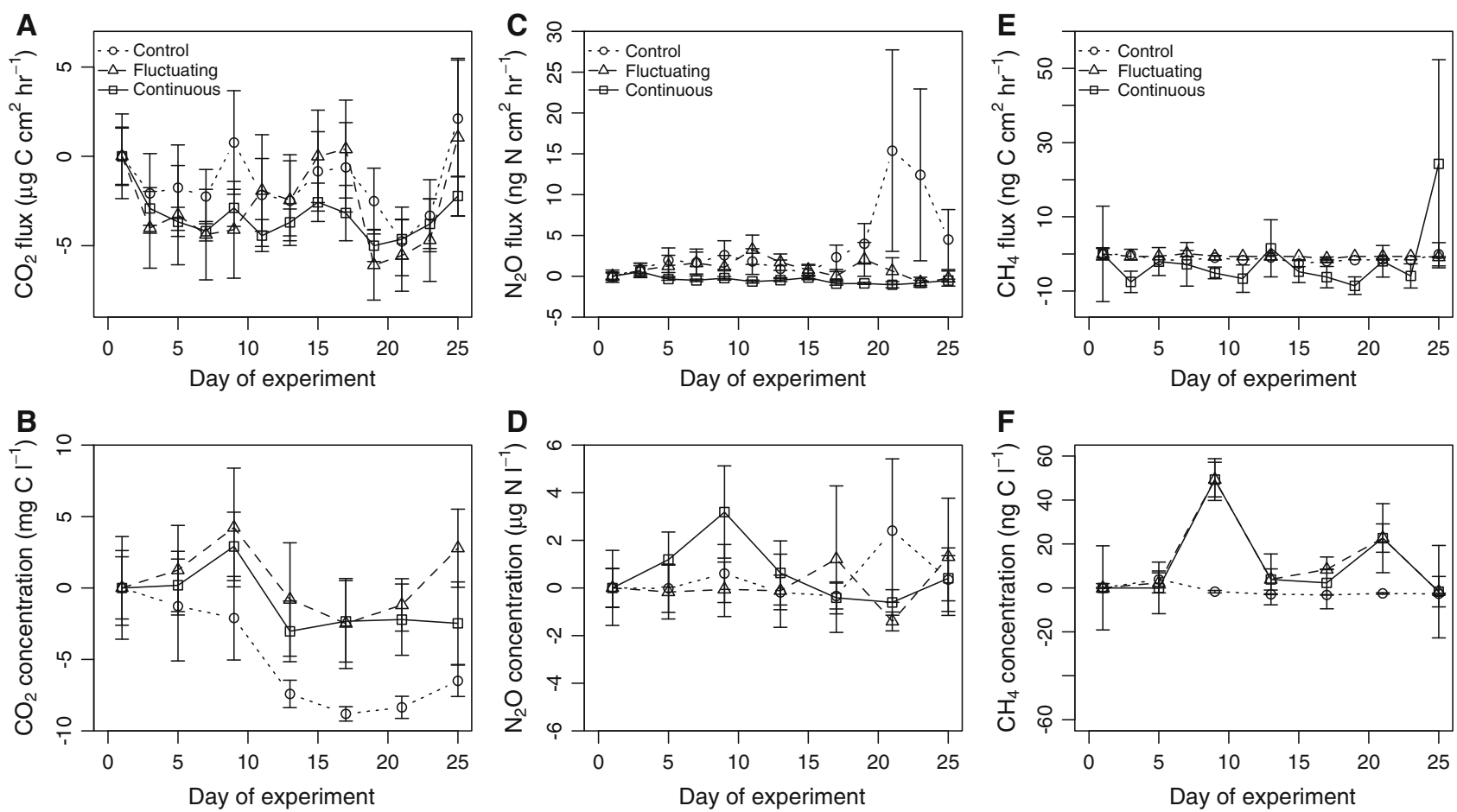

Figure 4. Normalized $( \pm \mathrm{SE})$ soil-atmosphere fluxes and soil concentrations $\left(10 \mathrm{~cm}\right.$ depth) of $\mathrm{CO}_{2}, \mathrm{~N}_{2} \mathrm{O}$, and $\mathrm{CH}_{4}$.
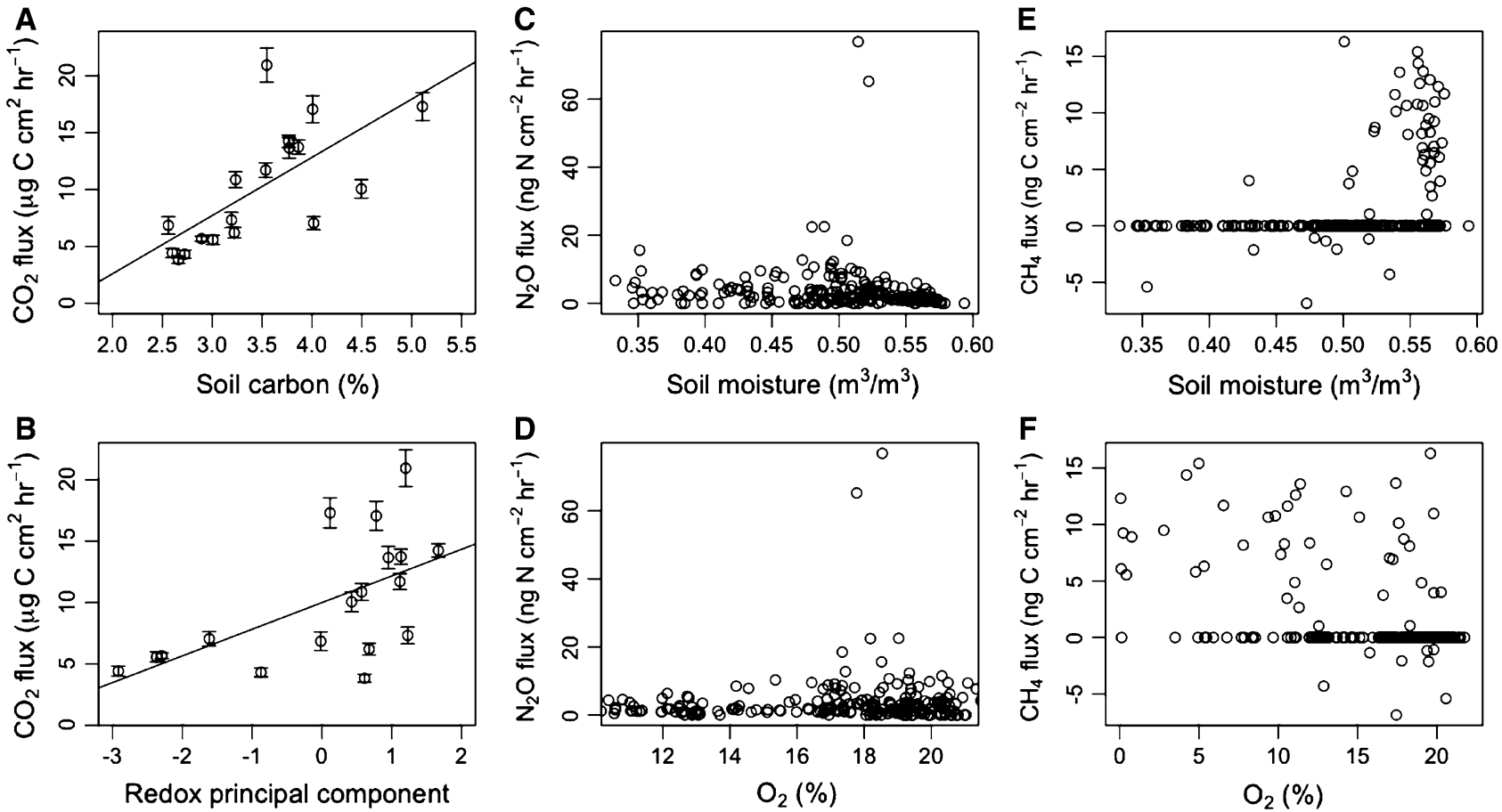

Figure 5. Pairwise relationships between greenhouse gas fluxes and covariates. Mean $\mathrm{CO}_{2}$ fluxes plotted against soil $\mathrm{C}$ concentrations $(\mathbf{A})$ and the composite redox indicator $(\mathbf{B})$. Individual $\mathrm{N}_{2} \mathrm{O}$ fluxes plotted against soil moisture $(\mathbf{C})$ and $\mathrm{O}_{2}$ (D), and $\mathrm{CH}_{4}$ fluxes plotted against soil moisture $(\mathbf{E})$ and $\mathrm{O}_{2}(\mathbf{F})$. 
contrary to our first prediction moisture explained comparatively little temporal variability in indicators of redox reactions, including $\mathrm{O}_{2}, \mathrm{NO}_{3}, \mathrm{Mn}(\mathrm{II})$, $\mathrm{Fe}(\mathrm{II})$, and $\mathrm{CH}_{4}$ concentrations. The temporal variation in soil moisture that we observed over the scale of days was equivalent to seasonal variation in moisture measured in other humid tropical forests (Kursar and others 1995; Koehler and others 2009; Wieder and others 2011). The relative decoupling between moisture and redox processes in this upland humid tropical forest contrasts with data from wetlands emphasizing the predominant role of moisture in controlling the spatial and temporal segregation of redox reactions (Patrick and Jugsujinda 1992; Achtnich and others 1995; Ratering and Conrad 1998; Yao and others 1999). In our study, we found that concentrations of redox species co-varied according to thermodynamic predictions within plots, but we observed little segregation of distinct redox reactions within plots over time. That is, aerobic respiration, denitrification, $\mathrm{Mn}$ reduction, Fe reduction, and methanogenesis all apparently occurred in close spatial proximity (within a given plot). Furthermore, extended periods of elevated soil moisture did not drive temporal patterns in redox chemical species, with the possible exception of $\mathrm{Fe}$ (II) concentrations which ultimately increased, and $\mathrm{NO}_{3}{ }^{-}$which decreased in continuously watered plots. The co-occurrence of multiple aerobic and anaerobic metabolic processes suggests the importance of aggregate-scale spatial variation in moisture, $\mathrm{O}_{2}$, and electron acceptor availability, which facilitate the co-occurrence of multiple redox reactions that would not likely persist in a spatially homogenous environment.

Although denitrification has long been known to occur within anaerobic soil aggregates in an otherwise aerobic environment (Sexstone and others 1985), we also measured considerable extractable $\mathrm{Mn}, \mathrm{Fe}(\mathrm{II})$, and $\mathrm{CH}_{4}$ at soil moisture below field capacity concomitant with abundant soil $\mathrm{O}_{2}$ (a mean of $16 \%$ over the experiment). Net $\mathrm{Mn}$ reduction occurred in all treatments, including plots where moisture declined well below field capacity, and soil $\mathrm{Fe}(\mathrm{II})$ concentrations were relatively high even in these drier plots. The high affinity of these clay-rich soils for moisture and their well-developed aggregate structure could explain the persistence of anaerobic microsites even under relatively drier conditions. Fimmen and others (2008) suggested that labile C supply stimulates $\mathrm{Fe}$ reduction in rhizosphere soil, providing an additional mechanism for generating anaerobic microsites even when macropores contain $\mathrm{O}_{2}$. Net positive $\mathrm{Mn}$ and Fe reduction in a dominantly aerobic soil environment likely masks even greater rates of gross $\mathrm{Mn}$ and $\mathrm{Fe}$ reduction, given that $\mathrm{Mn}(\mathrm{II})$ and $\mathrm{Fe}(\mathrm{II})$ should oxidize in the presence of $\mathrm{O}_{2}$. Indeed, increases in soil lysimeter solution $\mathrm{Fe}$ (II) concentrations suggest gross Fe reduction (Fe reduction followed by oxidation) even in control plots.

Concentrations of $\mathrm{O}_{2}$ and a principal component summarizing variation among measured redox species exhibited nonlinear threshold responses to moisture, but sustained high moisture did not usually deplete $\mathrm{O}_{2}$, and many plots showed nearatmospheric $\mathrm{O}_{2}$ concentrations despite sustained periods with moisture exceeding field capacity. These data suggest that high soil moisture is necessary but not sufficient to deplete macropore $\mathrm{O}_{2}$ in upland humid tropical forests. Additionally, infiltrating water could provide a significant source of $\mathrm{O}_{2}$. Our water-addition treatment could have supplied up to $2.5 \mathrm{~g} \mathrm{O}_{2} \mathrm{~m}^{-2}$ day $^{-1}$ if added water had completely equilibrated with soil porewater, which is theoretically sufficient to account for the majority of $\mathrm{C}$ oxidation to $\mathrm{CO}_{2}$ that we observed. It is likely, however, that water addition did not greatly contribute to $\mathrm{O}_{2}$ supply given the importance of rapid preferential flow in this ecosystem, which precludes substantial $\mathrm{O}_{2}$ exchange (McDowell and others 1992). In agreement with our results, water supplementation to soils in Panama caused only a small $(1.4 \%)$ decrease in bulk soil $\mathrm{O}_{2}$ concentrations (Kursar and others 1995). During this experiment, we also observed soil oligochaeta (earthworm) burrowing activity that increased within minutes of applying water to plots, leaving soil casts greater than $1 \mathrm{~cm}$ diameter on the soil surface. Worms were documented to mitigate hypoxia in marine sediments by burrowing (Norkko and others 2011). We suggest that an increase of faunal burrowing activity following precipitation events and $\mathrm{O}_{2}$ supply from rainwater could help explain the observed decoupling between moisture and $\mathrm{O}_{2}$ in soils with moisture contents above field capacity.

Combining our present data with previous research provides a more nuanced understanding of relationships between precipitation and soil $\mathrm{O}_{2}$ concentrations. Previous $\mathrm{O}_{2}$ measurements near our study site correlated negatively with cumulative rainfall measured over 28 -day periods, and with trends in hourly rainfall over periods of 10-16 days (Silver and others 1999; Liptzin and others 2011). Rainfall frequency rather than magnitude had a greater influence on $\mathrm{O}_{2}$ concentrations in these studies. We hypothesize that the minimal temporal response of $\mathrm{O}_{2}$ concentrations to 
water addition that we documented in this study may have been partly constrained by underlying long-term rainfall dynamics: rainfall events were frequent before the study began. Consequently, constitutive spatial variation may be responsible for the highly significant pairwise relationship between moisture and $\mathrm{O}_{2}$ that we observed. The relative unresponsiveness of $\mathrm{O}_{2}$ to large short-term variation in moisture documented here suggests caution in extrapolating long-term relationships between moisture and $\mathrm{O}_{2}$ to short-term dynamics.

\section{Controls on Greenhouse Gas Fluxes}

Fluxes of $\mathrm{CO}_{2}$ and $\mathrm{CH}_{4}$ exhibited relatively little temporal variability in response to high variation in soil moisture throughout our experiment. Contrary to our prediction, sustained high moisture neither suppressed $\mathrm{CO}_{2}$ fluxes nor stimulated $\mathrm{CH}_{4}$ fluxes, suggesting the resistance of microbial $\mathrm{C}$ cycling processes and/or root respiration. Modeled diffusivity showed little correlation with gas fluxes, suggesting that differences in biological rates as opposed to physical constraints governed variation among plots. These results contrast with data from temperate soils with comparable $\mathrm{C}$ concentrations that show an inhibition of organic matter decomposition as soil moisture exceeds field capacity (Linn and Doran 1984), an assumption incorporated in prominent ecosystem biogeochemical models ( $\mathrm{Li}$ and others 1992; Parton and others 1993). The response of humid tropical forest soil microbial communities to variation in moisture and $\mathrm{O}_{2}$ availability could be distinct from that of temperate ecosystems. In soil from our site, microbial biomass and taxonomic richness were greatest under conditions of fluctuating $\mathrm{O}_{2}$ availability relative to static aerobic conditions (Pett-Ridge and Firestone 2005). From a microbial perspective, consistently high soil moisture could represent an appropriate reference condition in this ecosystem, whereas declines in moisture might impose greater stress. Indeed, Wood and Silver (2012) recently documented a suppressive effect of experimental drought on soil $\mathrm{CO}_{2}$ fluxes from this ecosystem.

Mean soil $\mathrm{CO}_{2}$ fluxes were best predicted by soil C concentrations and a principal component integrating the relative abundance of five redox-active chemical species. This model suggests that $C$ substrate availability provides a first-order predictor of respiration that is further impacted by plot-specific differences in anaerobiosis. The principal component summarizing variation in five different redox reactions provided better explanatory power for $\mathrm{CO}_{2}$ fluxes than $\mathrm{O}_{2}$ concentrations alone, suggesting the importance of accounting for multiple co-occurring anaerobic processes in addition to aerobic respiration. Cleveland and others (2010) found a significant negative relationship between $\mathrm{O}_{2}$ concentrations and $\mathrm{CO}_{2}$ fluxes in a lowland tropical forest over the scale of months, and suggested that a combination of anaerobiosis and dilution of DOC could explain declines in $\mathrm{CO}_{2}$ fluxes under wet conditions. In our experiment, lysimeter DOC concentrations did not decline in rainfall addition treatments relative to controls, suggesting that $\mathrm{C}$ substrate limitation due to water addition was not likely an overriding factor over the timescale of our study.

We documented significant interactive effects of moisture and $\mathrm{O}_{2}$ availability on $\mathrm{N}_{2} \mathrm{O}$ fluxes consistent with the "hole in the pipe" model, which predicts that rates of $\mathrm{N}$ cycling and diffusion will control $\mathrm{N}_{2} \mathrm{O}$ fluxes (Davidson and others 2000). In our study, extractable and lysimeter $\mathrm{NO}_{3}$ concentrations increased in control and fluctuating wateraddition plots during periods of low soil moisture, likely fueling subsequent $\mathrm{N}_{2} \mathrm{O}$ production. High moisture and low $\mathrm{O}_{2}$ concentrations likely suppressed $\mathrm{N}_{2} \mathrm{O}$ fluxes due to decreased $\mathrm{NO}_{3}$ supply from nitrification and increased denitrification to $\mathrm{N}_{2}$. In other humid tropical forest soils, moisture correlated positively with $\mathrm{N}_{2} \mathrm{O}$ fluxes (Keller and Reiners 1994; Erickson and others 2001; Kiese and Butterbach-Bahl 2002; Koehler and others 2009; Rowlings and others 2012), but $\mathrm{N}_{2} \mathrm{O}$ fluxes often display a Gaussian distribution across the entire range of potential soil moisture characterized by declines under very wet conditions (Kiese and Butterbach-Bahl 2002; Castellano and others 2010). Our data support the results of Wieder and others (2011) and suggest that inhibitory effects of moisture on $\mathrm{N}_{2} \mathrm{O}$ fluxes may dominate in high rainfall environments. We found that sustained high soil moisture was consistently associated with high soil $\mathrm{N}_{2} \mathrm{O}$ concentrations, but low $\mathrm{N}_{2} \mathrm{O}$ fluxes suggestive of reduction to $\mathrm{N}_{2}$. The highest $\mathrm{N}_{2} \mathrm{O}$ fluxes occurred in control plots where moisture declined and subsequently increased due to rainfall events, resulting in lower soil moisture than the fluctuating plots and potentially creating an optimum combination of substrate availability, moisture, and $\mathrm{O}_{2}$ for nitrification/denitrification.

Several plots showed consistently positive net $\mathrm{CH}_{4}$ fluxes over the experiment and were unaffected by water-addition treatments, whereas others fluctuated between small net $\mathrm{CH}_{4}$ sources or sinks. Surprisingly, almost all positive $\mathrm{CH}_{4}$ fluxes occurred in the presence of measurable bulk soil $\mathrm{O}_{2}$ concentrations. Liptzin and others (2011) found an inverse correlation between $\mathrm{O}_{2}$ and soil $\mathrm{CH}_{4}$ 
concentrations over the scale of months in nearby sites, but our present data suggest caution in extrapolating from soil $\mathrm{CH}_{4}$ concentrations to surface fluxes, as concentrations of $\mathrm{CH}_{4}$ typically exceeded atmospheric levels even in the absence of net surface efflux. Variation in $\mathrm{CH}_{4}$ oxidation may control the direction of fluxes in these soils (Teh and others 2005; Rowlings and others 2012), where several plots fluctuated between $\mathrm{CH}_{4}$ sources and sinks. Notably, however, soil $\mathrm{CH}_{4}$ fluxes did not increase in response to continuous water addition in our study. In wetland ecosystems, $\mathrm{CH}_{4}$ production is typically suppressed until alternative electron acceptors are depleted during periods of sustained flooding (Ratering and Conrad 1998; Megonigal and others 2003; Yu and others 2007). In upland humid tropical forests, spatial heterogeneity of redox processes or high electron donor concentrations could allow gross $\mathrm{CH}_{4}$ production despite the presence of alternative electron acceptors. The lack of correlation among $\mathrm{CH}_{4}$ fluxes, moisture, and bulk soil $\mathrm{O}_{2}$ concentrations further supports the importance of anaerobic microsites in controlling $\mathrm{CH}_{4}$ fluxes. We cannot rule out that $\mathrm{CH}_{4}$ is produced from soil below our measurement zone, but surface soils showed high potential methanogenesis (Chacon and others 2006) and soils are shallow (30-40 $\mathrm{cm}$ to saprolite) at our particular study site. In sum, our data suggest that sustained high soil moisture will not necessarily induce a spike in $\mathrm{CH}_{4}$ production in upland humid tropical soils, in contrast to wetland soils where duration of flooding appears critical for predicting electron-acceptor depletion and $\mathrm{CH}_{4}$ fluxes (Ratering and Conrad 1998; Knorr and Blodau 2009), and in contrast to a seasonally dry tropical forest where irrigation treatments sometimes stimulated net positive $\mathrm{CH}_{4}$ fluxes (Vasconcelos and others 2004). Although $\mathrm{CH}_{4}$ fluxes tended to increase with our integrated measure of anaerobiosis, concentrations of labile Fe oxides measured in a separate study (S. Hall, data not shown) typically exceeded Fe(II) pools by at least one order of magnitude in all soils measured, indicating substantial potential for Fe reduction. Our data point to the importance of localized $\mathrm{CH}_{4}$ production "hot-spots" that persist despite the widespread presence of alternative electron acceptors.

\section{Implications for Climate Change}

The impact of climate change on precipitation regimes in humid tropical ecosystems remains highly uncertain, yet empirical and theoretical evidence points to an increase in the magnitude, variability, and importance of extreme events in some regions (Karl and others 1995; Romps 2011). Our data suggest that short-term increases in precipitation over the scale of weeks may have little additional impact on $\mathrm{CO}_{2}$ and $\mathrm{CH}_{4}$ fluxes from upland humid tropical forests. Such precipitation variability appears increasingly common at our site, reflected in highly variable inter-annual rainfall between 1989 and 2011 (2600-5800 $\mathrm{mm} \mathrm{y}^{-1}$, F. Scatena, unpublished data). Our results contrast with temperate wetland ecosystems, where variation in precipitation and water levels appear to play a defining role in constraining $\mathrm{O}_{2}$ availability, terminal electron-accepting processes, and greenhouse gas fluxes (Ponnamperuma 1972; Ratering and Conrad 1998; Jungkunst and Fiedler 2007; Knorr and Blodau 2009). The TEAP model, which posits that terminal electron acceptors will be reduced according to thermodynamic favorability during periods of high moisture, may be less useful for understanding plot-scale dynamics in upland humid tropical forests given their high spatial heterogeneity. Spatial segregation of redox processes within soil aggregates likely allows $\mathrm{Mn}$ and $\mathrm{Fe}$ reduction and methanogenesis to occur despite the close proximity of $\mathrm{O}_{2}$. Given adequate baseline moisture availability, increased precipitation may have relatively little impact on microbial processes occurring at the aggregate scale. Droughts that cross a moisture threshold where anaerobic microsites disappear, however, may provoke a stronger biogeochemical response.

\section{ConClusions}

We found that sustained high and variable soil moisture regimes had relatively little impact on soil redox biogeochemical processes and greenhouse gas fluxes from a humid tropical forest soil over a 25-day field experiment. Pairwise relationships between moisture and redox indicators that reflect constitutive spatial soil heterogeneity, however, did show significant relationships in spite of relatively weak effects from water-addition treatments themselves. These results suggest that moisture provides an adequate proxy for spatial variation in redox reactions, but less utility for predicting temporal variation over the timescale of our study. Although spatial variability in bulk soil $\mathrm{O}_{2}$ concentrations and trace gas fluxes generally exceeded temporal variability, we documented relatively large temporal variation in $\mathrm{NO}_{3}, \mathrm{Mn}(\mathrm{II})$, and $\mathrm{Fe}(\mathrm{II})$ pools. Anaerobic redox processes co-occurred with relatively high $\mathrm{O}_{2}$ concentrations in close proximity, showing a relative decoupling between moisture and $\mathrm{O}_{2}$ at the 
plot scale. Overall, our data suggest that the TEAP model of sequential electron-acceptor depletion over timescales of days to weeks is not a useful conceptual model of redox-sensitive biogeochemistry in this ecosystem. We observed net Fe reduction and a non-significant increase in $\mathrm{CH}_{4}$ flux in the continuous water-addition treatment at the end of the experiment, suggesting that long-term periods ( $>24$ days) of sustained soil moisture exceeding field capacity might ultimately stimulate anaerobic processes beyond background rates. Such sustained rainfall, however, is difficult to envision given the present stochasticity of precipitation at this site.

Mean soil $\mathrm{CO}_{2}$ fluxes displayed a negative relationship with reducing conditions, as predicted by thermodynamic theory, but surprisingly, water additions did not suppress $\mathrm{CO}_{2}$ fluxes over the timescale of our study. Biogeochemical models typically incorporate inhibitory effects of moisture on soil respiration. Our results suggest that soil respiration in humid tropical forests may be resistant to short-term (days-weeks) increases in moisture, and suggest caution in applying models developed for temperate soils in humid tropical ecosystems. Furthermore, water supplementation consistently suppressed $\mathrm{N}_{2} \mathrm{O}$ fluxes, contrasting with results from relatively drier ecosystems. Longer experiments encompassing a broader range of moisture conditions and humid tropical ecosystems are necessary to confirm these findings. A relatively wide range of soil moisture may have little short-term impact on $\mathrm{CO}_{2}$ and $\mathrm{CH}_{4}$ fluxes from humid tropical forests, questioning the representation of these processes in current biogeochemical models.

\section{ACKNOWLEDGMENTS}

We thank D. Kirschner for herculean field assistance, M. Almaraz, A. McDowell, J. Potter, C. Torrens, and S. van Bloem for logistics, and R. Rhew and two anonymous reviewers for comments. SJH was supported by the Department of Energy Office of Science Graduate Fellowship Program (DOE SCGF), made possible in part by the American Recovery and Reinvestment Act of 2009, administered by ORISE-ORAU under contract no. DE-AC05-06OR23100. Funding was provided by NSF Grant EAR-08199072 to WLS, and the NSF Luquillo Critical Zone Observatory (EAR-0722476) with additional support provided by the USGS Luquillo WEBB program. This research was also supported by Grant DEB 0620910 from NSF to the Institute for Tropical Ecosystem Studies, University of Puerto Rico, and to the International Institute of Tropical Forestry USDA Forest Service, as part of the Luquillo Long-Term Ecological Research Program.

\section{OPEN ACCESS}

This article is distributed under the terms of the Creative Commons Attribution License which permits any use, distribution, and reproduction in any medium, provided the original author(s) and the source are credited.

\section{REFERENCES}

Achtnich C, Bak F, Conrad R. 1995. Competition for electron donors among nitrate reducers, ferric iron reducers, sulfate reducers, and methanogens in anoxic paddy soil. Biol Fert Soils 19:65-72.

Bloom AA, Palmer PI, Fraser A, Reay DS, Frankenberg C. 2010. Large-scale controls of methanogenesis inferred from methane and gravity spaceborne data. Science 327:322-5.

Castellano MJ, Schmidt JP, Kaye JP, Walker C, Graham CB, Lin H, Dell CJ. 2010. Hydrological and biogeochemical controls on the timing and magnitude of nitrous oxide flux across an agricultural landscape. Glob Change Biol 16:2711-20.

Chacon N, Silver WL, Dubinsky EA, Cusack DF. 2006. Iron reduction and soil phosphorus solubilization in humid tropical forests soils: the roles of labile carbon pools and an electron shuttle compound. Biogeochemistry 78:67-84.

Chambers JQ, Tribuzy ES, Toledo LC, Crispim BF, Higuchi N, dos Santos J, Araújo AC, Kruijt B, Nobre AD, Trumbore SE. 2004. Respiration from a tropical forest ecosystem: partitioning of sources and low carbon use efficiency. Ecol Appl 14:72-88.

Chapelle FH, McMahon PB, Dubrovsky NM, Fujii RF, Oaksford ET, Vroblesky DA. 1995. Deducing the distribution of terminal electron-accepting processes in hydrologically diverse groundwater systems. Water Resour Res 31:359-71.

Cleveland CC, Wieder WR, Reed SC, Townsend AR. 2010. Experimental drought in a tropical rain forest increases soil carbon dioxide losses to the atmosphere. Ecology 91: 2313-23.

Davidson EA, Janssens IA. 2006. Temperature sensitivity of soil carbon decomposition and feedbacks to climate change. Nature 440:165-73.

Davidson EA, Trumbore SE. 1995. Gas diffusivity and production of $\mathrm{CO}_{2}$ in deep soils of the eastern Amazon. Tellus B 47: 550-65.

Davidson EA, Keller M, Erickson HE, Verchot LV, Veldkamp E. 2000. Testing a conceptual model of soil emissions of nitrous and nitric oxides. Bioscience 50:667-80.

do Carmo JB, Keller M, Dias JD, Camargo PB, de Frankenberg C, Crill P. 2006. A source of methane from upland forests in the Brazilian Amazon. Geophys Res Lett 33:L04809.

Dubinsky EA, Silver WL, Firestone MK. 2010. Tropical forest soil microbial communities couple iron and carbon biogeochemistry. Ecology 91:2604-12.

Erickson HE, Keller M, Davidson EA. 2001. Nitrogen oxide fluxes and nitrogen cycling during postagricultural succession and forest fertilization in the humid tropics. Ecosystems $4: 67-84$. 
Fimmen RL, deB Richter D, Vasudevan D, Williams MA, West LT. 2008. Rhizogenic Fe-C redox cycling: a hypothetical biogeochemical mechanism that drives crustal weathering in upland soils. Biogeochemistry 87:127-41.

Heartsill-Scalley T, Scatena FN, Estrada C, McDowell WH, Lugo AE. 2007. Disturbance and long-term patterns of rainfall and throughfall nutrient fluxes in a subtropical wet forest in Puerto Rico. J Hydrol 333:472-85.

Hedin LO, von Fischer JC, Ostrom NE, Kennedy BP, Brown MG, Robertson GP. 1998. Thermodynamic constraints on nitrogen transformations and other biogeochemical processes at soilstream interfaces. Ecology 79:684-703.

Huffaker L. 2002. Soil survey of Caribbean National Forest and Luquillo Experimental Forest, Commonwealth of Puerto Rico.

Itoh M, Ohte N, Koba K. 2009. Methane flux characteristics in forest soils under an East Asian monsoon climate. Soil Biol Biochem 41:388-95.

Jobbagy EG, Jackson RB. 2000. The vertical distribution of soil organic carbon and its relation to climate and vegetation. Ecol Appl 10:423-36.

Jungkunst HF, Fiedler S. 2007. Latitudinal differentiated water table control of carbon dioxide, methane and nitrous oxide fluxes from hydromorphic soils: feedbacks to climate change. Glob Change Biol 13:2668-83.

Karl TR, Knight RW, Plummer N. 1995. Trends in high-frequency climate variability in the twentieth century. Nature 377:217-20.

Keller M, Reiners WA. 1994. Soil-atmosphere exchange of nitrous oxide, nitric oxide, and methane under secondary succession of pasture to forest in the Atlantic lowlands of Costa Rica. Global Biogeochem Cycles 8:399-409.

Keller M, Weitz AM, Bryan B, Rivera MM, Silver WL. 2000. Soil-atmosphere nitrogen oxide fluxes: effects of root disturbance. J Geophys Res-Atmos 105:17693-8.

Kiese R, Butterbach-Bahl K. 2002. $\mathrm{N}_{2} \mathrm{O}$ and $\mathrm{CO}_{2}$ emissions from three different tropical forest sites in the wet tropics of Queensland, Australia. Soil Biol Biochem 34:975-87.

Knorr K, Blodau C. 2009. Impact of experimental drought and rewetting on redox transformations and methanogenesis in mesocosms of a northern fen soil. Soil Biol Biochem 41: 1187-98.

Koehler B, Corre MD, Veldkamp E, Wullaert H, Wright SJ. 2009. Immediate and long-term nitrogen oxide emissions from tropical forest soils exposed to elevated nitrogen input. Glob Change Biol 15:2049-66.

Kursar TA, Wright SJ, Radulovich R. 1995. The effects of the rainy season and irrigation on soil water and oxygen in a seasonal forest in Panama. J Trop Ecol 11:497-515.

Li C, Frolking S, Frolking TA. 1992. A model of nitrous oxide evolution from soil driven by rainfall events: 1 . Model structure and sensitivity. J Geophys Res 97:9759-76.

Linn DM, Doran JW. 1984. Effect of water-filled pore space on carbon dioxide and nitrous oxide production in tilled and non-tilled soils. Soil Sci Soc Am J 48:1267-72.

Liptzin D, Silver WL. 2009. Effects of carbon additions on iron reduction and phosphorus availability in a humid tropical forest soil. Soil Biol Biochem 41:1696-702.

Liptzin D, Silver WL, Detto M. 2011. Temporal dynamics in soil oxygen and greenhouse gases in two humid tropical forests. Ecosystems 14:171-82.

Matson PA, Vitousek PM. 1990. Ecosystem approach to a global nitrous oxide budget. Bioscience 40:667-72.
Matthias AD, Yarger DN, Weinbeck RS. 1978. A numerical evaluation of chamber methods for determining gas fluxes. Geophys Res Lett 5:765-8.

McDowell WH, Bowden WB, Asbury CE. 1992. Riparian nitrogen dynamics in two geomorphologically distinct tropical rain forest watersheds: subsurface solute patterns. Biogeochemistry 18:53-75.

Megonigal JP, Hines ME, Visscher PT. 2003. 8.08-anaerobic metabolism: linkages to trace gases and aerobic processes. In: Holland HD, Turekian KK, Eds. Treatise on geochemistry. Oxford: Pergamon. p 317-424.

Millington RJ, Shearer RC. 1971. Diffusion in aggregated porous media. Soil Sci 111:372-8.

Norkko J, Reed DC, Timmermann K, Norkko A, Gustafsson BG, Bonsdorff E, Slomp CP, Carstensen J, Conley DJ. 2011. A welcome can of worms? Hypoxia mitigation by an invasive species. Glob Change Biol 18:422-34.

Odum HT, Pigeon RF, 1970. Commission USAE. Rain forest structure and mineral-cycling homeostasis. In: A tropical rain forest: a study of irradiation and ecology at El Verde, Puerto Rico. Division of Technical Information, US Atomic Energy Commission

Parton WJ, Scurlock JMO, Ojima DS, Gilmanov TG, Scholes RJ, Schimel DS, Kirchner T, Menaut J-C, Seastedt T, Moya EG et al. 1993. Observations and modeling of biomass and soil organic matter dynamics for the grassland biome worldwide. Global Biogeochem Cycles 7:785-809.

Patrick WH, Jugsujinda A. 1992. Sequential reduction and oxidation of inorganic nitrogen, manganese, and iron in flooded soil. Soil Sci Soc Am J 56:1071-3.

Peretyazhko T, Sposito G. 2005. Iron(III) reduction and phosphorous solubilization in humid tropical forest soils. Geochim Cosmochim Acta 69:3643-52.

Pett-Ridge J, Firestone MK. 2005. Redox fluctuation structures microbial communities in a wet tropical soil. Appl Environ Microbiol 71:6998-7007.

Pinheiro J, Bates D, DebRoy S, Sarkar D, R Core Development Team. 2011. nlme: linear and nonlinear mixed effects models.

Ponnamperuma FN. 1972. The chemistry of submerged soils. Adv Agron 24:29-96.

Raich JW, Schlesinger WH. 1992. The global carbon dioxide flux in soil respiration and its relationship to vegetation and climate. Tellus B 44:81-99.

Ratering S, Conrad R. 1998. Effects of short-term drainage and aeration on the production of methane in submerged rice soil. Glob Change Biol 4:397-407.

Romps DM. 2011. Response of tropical precipitation to global warming. J Atmos Sci 68:123-38.

Rowlings DW, Grace PR, Kiese R, Weier KL. 2012. Environmental factors controlling temporal and spatial variability in the soil-atmosphere exchange of $\mathrm{CO}_{2}, \mathrm{CH}_{4}$ and $\mathrm{N}_{2} \mathrm{O}$ from an Australian subtropical rainforest. Glob Change Biol 18:726-38.

Scatena FN. 1989. An introduction to the physiography and history of the Bisley experimental watersheds in the Luquillo Mountains of Puerto Rico. USDA Forest Service General Technical Report. SO-72:1-22.

Schuur EAG, Matson PA. 2001. Net primary productivity and nutrient cycling across a mesic to wet precipitation gradient in Hawaiian montane forest. Oecologia 128:431-42.

Sexstone AJ, Revsbech NP, Parkin TB, Tiedje JM. 1985. Direct measurement of oxygen profiles and denitrification rates in soil aggregates. Soil Sci Soc Am J 49:645-51. 
Silver WL, Lugo AE, Keller M. 1999. Soil oxygen availability and biogeochemistry along rainfall and topographic gradients in upland wet tropical forest soils. Biogeochemistry 44:301-28.

Steudler PA, Melillo JM, Feigl BJ, Neill C, Piccolo MC, Cerri CC. 1996. Consequence of forest-to-pasture conversion on $\mathrm{CH}_{4}$ fluxes in the Brazilian Amazon Basin. J Geophys Res 101: 18547-54

Teh YA, Silver WL, Conrad ME. 2005. Oxygen effects on methane production and oxidation in humid tropical forest soils. Glob Change Biol 11:1283-97.

Thompson A, Chadwick OA, Rancourt DG, Chorover J. 2006. Iron-oxide crystallinity increases during soil redox oscillations. Geochim Cosmochim Acta 70:1710-27.

Vasconcelos SS, Zarin DJ, Capanu M, Littell R, Davidson EA, Ishida FY, Santos EB, Araújo MM, Aragão DV, RangelVasconcelos LGT, and others. 2004. Moisture and substrate availability constrain soil trace gas fluxes in an eastern Amazonian regrowth forest. Global Biogeochem Cycles. 18:GB 2009.

Vine H, Thompson H, Hardy F. 1942. Studies on aeration of cacao soils in Trinidad (II). Trop Agric 19:215-23.

Viollier E, Inglett PW, Hunter K, Roychoudhury AN, van Cappellen P. 2000. The ferrozine method revisited: $\mathrm{Fe}(\mathrm{II}) / \mathrm{Fe}(\mathrm{III})$ determination in natural waters. Appl Geochem 15:785-90.
Wieder WR, Cleveland CC, Townsend AR. 2011. Throughfall exclusion and leaf litter addition drive higher rates of soil nitrous oxide emissions from a lowland wet tropical forest. Glob Change Biol 17:3195-207.

Wood SN. 2006. Generalized additive models: an introduction with R. Boca Raton (FL): CRC Press. 422pp.

Wood T, Silver WL. 2012. Strong spatial variability in trace gas dynamics following experimental drought in a humid tropical forest. Global Biogeochem Cycles. 26:GB3005.

Yang WH, Herman D, Liptzin D, Silver WL. 2012. A new approach for removing iron interference from soil nitrate analysis. Soil Biol Biochem 46:123-8.

Yao H, Conrad R, Wassmann R, Neue HU. 1999. Effect of soil characteristics on sequential reduction and methane production in sixteen rice paddy soils from China, the Philippines, and Italy. Biogeochemistry 47:269-95.

Yu KW, Bohme F, Rinklebe J, Neue HU, DeLaune RD. 2007. Major biogeochemical processes in soils-a microcosm incubation from reducing to oxidizing conditions. Soil Sci Soc Am J 71:1406-17.

Yu KW, Faulkner SP, Baldwin MJ. 2008. Effect of hydrological conditions on nitrous oxide, methane, and carbon dioxide dynamics in a bottomland hardwood forest and its implication for soil carbon sequestration. Glob Change Biol 14:798-812. 